\title{
Recycling Process of the Aluminium Cans as an Element of the Sustainable Development Concept
}

Manuela Ingaldi, Stanisław Borkowski

Faculty of Management, Czestochowa University of Technology. al. Armii Krajowej 19b, $42-200$ Czestochowa. Poland. E-mail: manuela@gazeta.pl,bork@zim.pcz.pl

Introduction into problems - An idea of recycling is related to the sustainable development concept, which enforces this process. One of the most often recycled material is aluminium. It is recovered primarily from used beverage cans. These cans are normally back on supermarket shelves as new beverage cans in 6-8 weeks. With a growing percentage of the cans made from aluminium, because of its lightweight qualities, this ensures a healthy market for aluminium can recycling. In the paper characteristics of aluminium and the process of its recycling are presented. Its recovery rate in Poland is shown. The analusis of possible use of preformed granules of aluminium scrap into liquid steel deoxidation was also conducted. The results of the research carried out in laboratory conditions clearly showed that the sample 4 from the third supplier, from the viewpoint of the cost of the technology used in steel deoxidation, is the least favourable.

Keywords: Aluminium, Used Beverage Containers, Recycling, Liquid Steel Deoxidation

\section{References}

[1] World commission on environment and development. "our common future, Chapter 2: towards sustainable development". Un-documents.net. Retrieved 2011-09-28

[2] KARDAS, E. (2013). The analysis of quality of ferrous burden materials and its effect on the parameters of blast furnace process. In: Metallurgy, Vol. 52 (2), p. 149-152

[3] KLIMECKA-TATAR, D. (2014). The Powdered Magnets Technology Improvement by Biencapsulation Method and Its Effect on Mechanical Properties. In: Manufacturing Technology, Journal For Science, Research And Production, Vol.14, No. 1, p.30-36

[4] KONSTANCIAK, A., BROŽOVÁ, S., PUSTĚJOVSKÁ, P. (2013). Wykorzystanie alternatywnych źródeł energii w Polsce i Republice Czeskiej. In: Rynek Energii, No 4 (107) p.33-36

[5] SYGUT, P., LABER, K., BORKOWSKI, S. (2012). Investigation of the non-uniform temperature distribution on the metallic charge length during round bars rolling process. In: Manufacturing Technology, Journal For Science, Research And Production, Vol. 12, No 13, p. 260-263

[6] KARDAS, E., BROŽOVA, S. (2013). Situation in Waste Treatment in Poland. In: METAL 2013. 22nd International Conference on Metallurgy and Materials. Conference Proceedings. May 15th - 17th 2013, Brno, Czech Republic, p. 1773-1778. TANGER Ltd., Ostrava

[7] INGALDI, M., SIERKA, E. (2012). Zarządzanie środowiskiem a efektywne zarządzanie przedsiębiorstwem, In: Wybrane zagadnienia produkcji i zarzadzania w przedsiębiorstwie. (A. Konstanciak, E. Kardas, (Ed.)), pp.146154. Pub. WIPMiFS PCz, Częstochowa

[8] NÁPRSTKOVÁ, N., KUŚMIERCZAK, S., CAIS J. (2013). Modification of AISi7Mg0.3 alloy by strontium. In: Manufacturing Technology, Journal For Science, Research And Production, Vol. 13, No 3, p. 373-380

[9] MICHNA, Š., NÁPRSTKOVÁ, N. (2012). The use of fractography in the analysis of cracking after formed workpiece blank mechanical machining from the AlCuSnBi alloy. In: Manufacturing Technology, Journal For Science, Research And Production, Vol. 12, No 13, p. 174-178

[10] SCHMITZ, C. (2006). Handbook of Aluminium Recycling. Vulkan Verlag. GmbH Essen

[11] DOBRZAŃSKI, L. (2002). Podstawy nauki o materiałach i materiałoznawstwie. Materiały inzynierskie z podstawami projektowania materialowego. Wydawnictwo Naukowo-Techniczne, Warszawa

[12] LITWIŃCZYK-KWAŚNICKA, M., ROZPONDEK, M., SIWKA, J. (2012). Influence the thermal process of the removing the varnish coats to the cleanness of the surface aluminium scrap. In: Materials Science Forum, Vol. 638-642, pp. 876-881

[13] Waste online: Metals - aluminium and steel recycling, http://dl.dropboxusercontent.com/u/21130258/ resources/InformationSheets/metals.htm (12.08.2013) 
[14] PUSTĚJOVSKÁ, P., JURSOVÁ, S. (2013). Process engineering in iron production. In: Chemical and Process Engineering - Inzynieria Chemiczna i Procesowa, No. 34 (1), p. 63-76

[15] BLACHA, L., SIWIEC, G., OLEKSIAK, B. (2013). Loss of aluminium during the process of Ti-Al-V alloy smelting in a vacuum induction melting (VIM) furnace. In: Metalurgija, Vol.52, Iss. 3, p. 301-304

[16] BLACHA, L., OLEKSIAK, B., SMALCERZ, A., MATUŁA, T. (2012). Changes in Ti-Al-Mn alloy compositions during their smelting in a vacuum induction furnace In: Archives of Materials Science and Engineering, Vol. 58, Iss. 1 , p. 28-32

[17] JANKOWSKI, M. (2012). Z małej puszki duży zysk, http://finanse.wp.pl/kat,1033821,title,Z-malej-puszki-duzyzysk, wid,14530965, wiadomosc.html?ticaid=11152a (15.08.2013)

[18] Fundacja na Rzecz Odzysku Opakowań Aluminiowych RECAL, http://www.recal.org.pl/ (10.08.2013)

[19] (2012) Rocznik statystyczny. Informacje i opracowania statystyczne, Główny Urząd Statystyczny, Warszawa

[20] NIESLER, M. (2005). Najlepsze Dostępne Techniki (BAT) wytyczne dla produkcji żelaza i stali huty zintegrowane. Ministerstwo Ochrony Środowiska, Warszawa

[21] CHMIELARZ, A., WĘŻYK, W., KAMIŃSKI, K., BRATEK, Ł., MALEC, W. (2007). Najlepsze Dostępne Techniki (BAT) wytyczne dla produkcji i przetwórstwa metali nieżelaznych. Ministerstwo Ochrony Środowiska, Warszawa

[22] PN-71/H-82162

[23] KONSTANCIAK, M. (2012). Analysis of technological strategies on the example of the production of the tramway wheels. In: Archives of Materials Science and Engineering Vol.57 Iss.2, p.69-74

[24] SELEJDAK, J. (2003). Influencing factors onto quality of welded pipes. In: Metalurgija, Vol. 42, Iss. 1, p.65-67 